\title{
BERRIES, THE ANTIOXIDANT SOURCES OF THE BOREAL COLD AND ARID REGIONS
}

\author{
D. Kleiner ${ }^{\text {a* }}$, D. Kurucz ${ }^{\text {a }}$ A. Bersényi ${ }^{\mathrm{b}}$, K. Szentmihályi ${ }^{\mathrm{c}}$, A. Skesters ${ }^{\text {d }}$, L. Zuka ${ }^{\mathrm{e}}$ \\ and A. BlázoviCs ${ }^{\mathrm{a}}$ \\ a Department of Pharmacognosy, Semmelweis University, H-1085 Budapest, Üllői út 26. Hungary \\ ${ }^{\mathrm{b}}$ Institute of Animal Breeding, Nutrition and Lab Animal Science, Faculty of Veterinary Science, \\ Szent István University, H-1078 Budapest, István út 2. Hungary \\ ${ }^{c}$ Institute of Materials and Environmental Chemistry Research Centre for Natural Sciences of the HAS, \\ H-1025 Budapest, PO Box 17. Hungary \\ d Riga Stradinsš University, RSU Dzirciema Str. 16, Riga, LV-1007. Latvia \\ e Silvanols Ltd., Kurbada Str. 2a, Riga, LV-1009. Latvia
}

(Received: 23 July 2014; accepted: 9 October 2014)

\begin{abstract}
Chronic gastrointestinal diseases are mostly attached to inflammation as well as modified redox homeostasis. These diseases cause remarkable health problems in the northern regions of Europe, but as the climate becomes colder, the harvesting of fruit with notable antioxidant content becomes harder. In these regions, polyphenol-rich berries, which can handle the climate, may have pivotal role in the diet. The aim of our study was to determine antioxidant properties of watery extracts of blueberry, Vaccinium corymbosum L., bilberry, V. myrtillus L., and lingonberry, V. vitis-idaea L. that may have role in the redox homeostasis of the gastrointestinal region. Data show that these berries notably inhibit the lipid peroxidation, underpinned by reducing power, total polyphenol and ascorbic acid content. The study demonstrates that berries can play a remarkable role in northern European diet, especially when redox homeostasis is imbalanced.
\end{abstract}

Keywords: blueberry, bilberry, lingonberry, antioxidant, chronic gastrointestinal diseases

It is well known that illnesses modify redox homeostasis, especially when the immune system is concerned, like in cases of inflammatory bowel disease or celiac disease. With the measurement of total scavenging capacity, BLÁzovics and co-workers (1999) supported that nonetheless the therapy, the redox homeostasis is always exhausted in Crohn's disease, but differences can be found between the activities of ulcerative colitis. Prevalence of diseases is high in northern regions and increases with age (TIмm et al., 2014). Another immune system related disorder is the celiac disease, when the inducers for the inflammation are some prolamin fractions from cereals (FERRETTI et al., 2012). Celiac disease is one of the most common genetically-determined enteropathies, and internal oxidative balance plays a pivotal role. The frequency of the disease is also higher in Northern Europe (GuJRAL et al., 2012). In cases of these gastrointestinal diseases, the supported idea is the need of a higher proportion of antioxidants, especially polyphenol-rich food, as dietary factors have a wide range of health-protective and anti-inflammatory effects (Ferretti et al., 2012; Nile \& PARK, 2014).

Nowadays, berries get increasing attention, because of their effects against civilizationillnesses. Most studies focus on their polyphenolic components, especially flavonoids, hydroxycinnamic acid derivatives, and anthocyanin content in their extracts (IERI et al., 2013;

\footnotetext{
* To whom correspondence should be addressed.

Phone: +36-1-4591500/55372; fax: +36-1-3172979; e-mail: deneskleiner@gmail.com
} 
NILE \& PARK, 2014). These compounds have significant antioxidant activities. Antioxidants as well as prooxidants have significant role in homeostasis, as members of the redox balance.

Anthocyanins are well known colorants in food industry and potent anticancer and neuroprotective agents with cardiovascular benefits as well (NILE \& PARK, 2014). Some studies demonstrated that anthocyanin derivatives have also urinary health benefits, but the most known antibacterial components of berries are arbutin and its derivatives. Therefore, in case of consumption, the content of toxic arbutin should be taken into consideration, as it is a hydroquinone derivate (Yang \& Jiang, 2010; Ieri et al., 2013; Nile \& PARK, 2014). According to our best knowledge, this compound is detected in lingonberry and blueberry (YANG \& JiANG, 2010; IERI et al., 2013). Recent studies also showed, that the urinary use of the polyphenol-rich herbs may have unexpected side effects, because they modulated and sometimes enhanced the bacterial antibiotic susceptibility (SAmollova et al., 2014).

The fruit contain high concentrations of vitamins as well, but recent study shows that only scarce of essential elements can be found in relevant amounts in blueberry, bilberry, and lingonberry (NILE \& PARK, 2014; SKesters et al., 2014).

Most of the berries have a substantial property that can handle the cold and arid climate. As a relevant antioxidant source, they are promising fruit to grow in the northern countries, for example in Latvia (Mikulic-Petкovsek et al., 2012; Skesters et al., 2014).

All in all, the berries have significant antioxidant contents, but the antioxidant properties can change in wide ranges in the species themselves as well as between species (IERI et al., 2013). Our aim was to determine the antioxidant properties, especially the inhibition of lipid peroxidation of blueberry, bilberry, and lingonberry available in the northern regions of Europe, to evaluate their protective effect in some gastrointestinal cases with disrupted redox homeostasis, which is a serious problem in this region.

\section{Materials and methods}

\subsection{Reagents}

Folin and Ciocalteu's phenol reagent and bovine serum albumin were obtained from SigmaAldrich Co. (St. Louis, USA). Potassium sodium tartrate $\times 4 \mathrm{H}_{2} \mathrm{O}, \mathrm{CuSO}_{4} \times 5 \mathrm{H}_{2} \mathrm{O}, \mathrm{Na}_{2} \mathrm{CO}_{3}$, $\mathrm{NaOH}$, trichloroacetic acid, 2-thiobarbituric acid, tris(hydroxymethyl)aminomethane (TRIS buffer), maleinic acid, $37 \%$ hydrochloric acid, gallic acid, 2,2-bipyridyl, $\mathrm{FeNH}_{4}\left(\mathrm{SO}_{4}\right)_{2} \times 12 \mathrm{H}_{2} \mathrm{O}$, $85 \%$ phosphorous acid, ammonium acetate, $\mathrm{K}_{3}\left[\mathrm{Fe}(\mathrm{CN})_{6}\right], \mathrm{FeCl}_{3} \times 6 \mathrm{H}_{2} \mathrm{O}, \mathrm{KH}_{2} \mathrm{PO}_{4}, \mathrm{Na}_{2} \mathrm{HPO}_{4}$, and $96 \%$ ethanol were obtained from Reanal-KER Ltd. (Budapest, Hungary).

Ascorbic acid and citric acid were suited for the requirements of Pharmacopoeia Hungarica VIII.

\subsection{Preparation of the berry extracts}

Blueberry (Vaccinium corymbosum L.), bilberry (Vaccinium myrtillus L.), and lingonberry (Vaccinium vitis-idaea L.) samples were from Latvia, collected in the woods near Riga or bought at the local market.

Lyophilisation was made with Heto Lyophilizer (HITOSICC, Heto-Holten A/S, Denmark). The dry matter was $12.22 \%$ in blueberry, $8.58 \%$ in bilberry, and $22.05 \%$ in lingonberry. After lyophilisation the samples were stored at room temperature. 
Extracts were made by pouring water on the lyophilised berry samples and incubating them for one day at room temperature. The concentration was adjusted to $1 \mathrm{~g}$ lyophilised berry sample in $10 \mathrm{ml}$ water. After filtration, the aqueous extracts were diluted to $0.05 \mathrm{~g} \mathrm{ml}^{-1}$ and $0.025 \mathrm{~g} \mathrm{ml}^{-1}$, and measured with the following methods.

\subsection{Total polyphenol content of the samples}

The total polyphenol content was measured according to Pharmacopoeia Hungarica VIII (National Institute of Pharmacy, 2003). The $0.2 \mathrm{ml}$ Folin and Ciocalteu's reagent was added to $0.4 \mathrm{ml}$ sample, $2.4 \mathrm{ml} \mathrm{Na}_{2} \mathrm{CO}_{3}\left(290 \mathrm{~g} \mathrm{l}^{-1}\right)$, and $2 \mathrm{ml}$ bidistilled water. Gallic acid standard was used. The blind was made by the same method, but instead of Folin and Ciocalteu's reagent, $0.2 \mathrm{ml} \mathrm{Na} \mathrm{CO}_{3}$ solution was used. After $30 \mathrm{~min}$, reagent solutions were measured at $760 \mathrm{~nm}$ with Hitachi U-2000 instrument. A gallic acid unit (GAU) is $1 \mathrm{mg}$ gallic acid in $1 \mathrm{ml}$ bidistilled water.

\subsection{Ascorbic acid content}

Ascorbic acid concentration was determined according to Pharmacopoeia Hungarica VII. (National Institute of Pharmacy, 1986). The $0.5 \mathrm{ml}$ samples and ascorbic acid standards were mixed with $0.1 \mathrm{ml} \mathrm{FeNH}_{4}\left(\mathrm{SO}_{4}\right)_{2}\left(0.1 \mathrm{~g} \mathrm{FeNH}_{4}\left(\mathrm{SO}_{4}\right)_{2} / 100 \mathrm{ml} 2 \mathrm{M}\right.$ phosphorous acid), 0.5

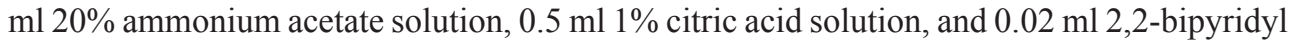
$(1 \mathrm{~g} / 100 \mathrm{ml}$ ethanol). After 2 hours, the solutions were diluted with $3.38 \mathrm{ml}$ bidistilled water and measured at $525 \mathrm{~nm}$ with Hitachi U-2000 spectrophotometer. The blanks were made from adequate samples; but instead of $0.02 \mathrm{ml}$ 2,2-dipyridyl, the samples were only diluted with $3.4 \mathrm{ml}$ bidistilled water.

\subsection{Reducing power of berries}

The reducing power was measured by the method of OyAIzU (1986). The $0.2 \mathrm{ml}$ sample was incubated with $0.8 \mathrm{ml}$ bidistilled water, $2.5 \mathrm{ml} \mathrm{pH}=6.6$ phosphate buffer, and $2.5 \mathrm{ml} 1 \%$ $\mathrm{K}_{3}\left[\mathrm{Fe}(\mathrm{CN})_{6}\right]$ solution at $37{ }^{\circ} \mathrm{C}$. After $30 \mathrm{~min}, 2.5 \mathrm{ml}$ trichloroacetic acid was added to the samples, and from this mixture $2.5 \mathrm{ml}$ were added to $0.5 \mathrm{ml} 0.1 \% \mathrm{FeCl}_{3}$ solution. The absorbance of the solution was measured with Hitachi U-2000 spectrophotometer at $700 \mathrm{~nm}$. Ascorbic acid was used as standard. An ascorbic acid unit (AAU) is $1 \mathrm{mg}$ ascorbic acid in 1 ml bidistilled water.

\subsection{Preparation of liver sample for measurement of lipid peroxidation inhibition}

The 5 broiler chickens were obtained from Babádi Chicken Hatchery Ltd. (Ócsa, Hungary). The broiler chickens were terminated, when 42 days old. The livers of the animals were removed and were homogenized. Protein content was measured according to LowRY and coworkers (1951). The pooled liver samples were diluted 100 times, and $1 \mathrm{ml}$ was given to $1 \mathrm{ml}$ of 1:1 mixture of Folin A reagent $\left(0.002 \mathrm{~g} \mathrm{ml}^{-1}\right.$ potassium sodium tartrate $\times 4 \mathrm{H}_{2} \mathrm{O}, 0.2 \mathrm{~g} \mathrm{ml}^{-1}$ $\mathrm{Na}_{2} \mathrm{CO}_{3}$, and $\left.0.04 \mathrm{~g} \mathrm{ml}^{-1} \mathrm{NaOH}\right)$ and Folin B reagent $\left(0.001 \mathrm{~g} \mathrm{ml}^{-1} \mathrm{CuSO}_{4} \times 5 \mathrm{H}_{2} \mathrm{O}\right)$. After 10 min, $4 \mathrm{ml}$ of diluted Folin and Ciocalteu's phenol reagent (1:17 Folin and Ciocalteu's phenol reagent:bidistilled water) was given to the sample, and incubated for $15 \mathrm{~min}$ at $37^{\circ} \mathrm{C}$ in a tempered bath. The reaction was stopped in an ice-cold bath and the absorbance of the solution was measured at $650 \mathrm{~nm}$. Parallels were made, and bovine serum albumin was the standard. The homogenate was diluted to $10 \mathrm{mg} \mathrm{ml}^{-1}$. 


\subsection{Inhibition of ascorbic acid-induced lipid peroxidation}

Samples $(0.05 \mathrm{ml})$ were incubated for $30 \mathrm{~min}$ with $0.01 \mathrm{ml} 50 \mathrm{mM} \mathrm{KH}_{2} \mathrm{PO}_{4}$ solution; $0.05 \mathrm{ml}$ $0.01 \mathrm{M}$ ascorbic acid solution; $0.05 \mathrm{ml} 0.5 \mathrm{mM} \mathrm{FeCl}_{3} ; 0.05 \mathrm{ml}$ liver homogenate; $0.05 \mathrm{ml}$ buffer (11.02 $\mathrm{g}$ TRIS buffer and $5.8 \mathrm{~g}$ maleinic acid in $100 \mathrm{ml}$ bidistilled water), and $0.25 \mathrm{ml}$ bidistilled water in $37{ }^{\circ} \mathrm{C}$ bath. After half an hour, $0.4 \mathrm{ml}$ solutions were added to $2 \mathrm{ml}$ thiobarbituric acid reagent $(250 \mathrm{ml} \mathrm{30 \%}$ trichloroacetic acid; $125 \mathrm{ml} 1 \mathrm{~N}$ hydrochloric acid; $1.875 \mathrm{~g}$ thiobarbituric acid, complemented to $500 \mathrm{ml}$ with bidistilled water) to measure the malondialdehyde. The mixtures were boiled in water for $15 \mathrm{~min}$. After centrifugation of the samples, absorbance (A) was measured at $535 \mathrm{~nm}$ with Hitachi U-2000 spectrophotometer. The control solutions were made by the same method as the samples, but from $0.05 \mathrm{ml}$ bidistilled water instead. Every blank of the samples were made from the adequate berry extract, but instead of liver, we used bidistilled water (HoRvÁtH et al., 1993).

The inhibition $\%$ of the lipid peroxidation was counted from the control:

$$
\text { inhibition } \%=100 \times\left(\mathrm{A}_{\text {sample }}-\mathrm{A}_{\text {control }}\right) / \mathrm{A}_{\text {control }}
$$

\section{Results and discussion}

As it was expected, prominently high polyphenol and ascorbic acid content was in bilberry, and the values of blueberry were higher than the values of lingonberry (Table 1). On the other hand, data may seem to be lower than those of other studies, as in the latter measurements a simple watery extraction was used, only one time, without organic solvents that could be used easily as a dietary supplement. In the study of JovančEvić and co-workers (2011), extraction was made with methanol and at least $3.9 \mathrm{mg}$ gallic acid equivalent was measured in $1 \mathrm{~g}$ of fresh bilberry, but in our study only $1.2 \mathrm{mg}$ gallic acid equivalent could be determined in $1 \mathrm{~g}$ fresh fruit. In the literature, for blueberry samples at least $170.9 \mathrm{mg}$ and for lingonberry at least $431 \mathrm{mg}$ gallic acid equivalent/100 $\mathrm{g}$ fresh fruit were measured after extraction three times with organic or organic containing solvents. In this study only 29.8 and $26.9 \mathrm{mg}$ gallic acid equivalent $/ 100 \mathrm{~g}$ fresh blueberry and lingonberry could be detected, respectively (LEE \& FinN, 2012; Kim et al., 2013). Same results were expected for ascorbic acid concentrations, when compared to total contents. In the Souci-Fachmann-Kraut database (2014), the mean of total ascorbic acid content was $22 \mathrm{mg}$ in $100 \mathrm{~g}$ edible bilberry. In our study only $5.5 \mathrm{mg}$ could be detected in the unattended, fresh samples. In the antioxidant measurements, remarkable differences were found among the three berry-extracts. The reducing power was the highest in bilberry, also the highest inhibition of lipid peroxidation was observed there (Table 2). This is in agreement with our previous studies (SKESTERs et al., 2014).

Table 1. Total polyphenol and ascorbic acid content (mean \pm standard deviation) in $0.05 \mathrm{~g} \mathrm{ml}^{-1}$ berry extract (Gallic Acid Unit=GAU)

\begin{tabular}{lccc}
\hline & Blueberry & Bilberry & Lingonberry \\
\hline Total polyphenol content (GAU) & $0.122 \pm 0.006$ & $0.691 \pm 0.010$ & $0.061 \pm 0.002$ \\
Ascorbic acid content $(\mathrm{mg} / 100 \mathrm{ml})$ & $2.254 \pm 0.038$ & $3.183 \pm 0.095$ & $0.639 \pm 0.057$ \\
\hline
\end{tabular}


Table 2. Inhibition of lipid peroxidation and reducing power (mean \pm standard deviation) in the $0.025 \mathrm{~g} \mathrm{ml}^{-1}$ berry extract (Ascorbic Acid Unit=AAU)

\begin{tabular}{lccc}
\hline & Blueberry & Bilberry & Lingonberry \\
\hline Inhibition of lipid peroxidation (\%) & $40.25 \pm 2.67$ & $65.57 \pm 8.23$ & $23.66 \pm 2.57$ \\
Reducing power (AAU) & $0.146 \pm 0.001$ & $0.439 \pm 0.006$ & $0.132 \pm 0.008$ \\
\hline
\end{tabular}

The properties of the lipid peroxidation levels can be attributed not only to the differences in ascorbic acid, but to the polyphenol content, too. On the other hand, these components may have pro-oxidant properties, for example in high doses or in the presence of metal ions (YORDI et al., 2012). Also, high dose ascorbic acid (at least $500 \mathrm{mg} \mathrm{day}^{-1}$ ) consumption can cause enhanced urination, etc. (RUTKOWSKI \& GRZEGORCZYK, 2012).

These chemicals are very favourable for the inhibition of inflammatory processes of bowel diseases during their contact reactions, as a remarkable amount of flavonoids stay in the bowel, and may inhibit intestinal lipid peroxidation (DEIANA et al., 2012; THILAKARATHNA \& Rupasinghe, 2013). In this case, the effects of the compounds are closer to our "in vitro" experiment, as the performed reaction was carried out at $37^{\circ} \mathrm{C}$ and iron was present at the same time, while ascorbic acid was the main source of reactive substrates.

All in all, the experiment showed the direct effects of the intact, watery extracts of berries against lipid peroxidation "in vitro", which may have a role in the prevention of enterocyte damage, membrane integrity, and inflammation in the bowel as well (DeIANA et al., 2012). This effect supports that berries are beneficial nutriment factors in inflammatory bowel disease as well as in the celiac disease, where the integrity of the bowel is well known to be disrupted.

The boreal spread of these fruit may have a subsequent benefit in case of celiac disease, which can be found in higher prevalence in the northern regions, but further clinical trials are needed to evaluate the effects of berries (FERRETTI et al., 2012; GuJRAL et al., 2012).

\section{Conclusions}

These "in vitro" data support the high antioxidant properties of these cold, lyophilised berry extracts. Even though only watery extracts were studied, the inhibition of lipid peroxidation was notable, underpinned by the remarkable reducing power, relatively high ascorbic acid and polyphenol contents. While the effects of the antioxidants on illnesses are widely examined, these experiments demonstrated the direct inhibitory effect of the lipid peroxidation that has role in the bowel, for example in the case of celiac disease.

\section{References}

Blázovics, A., Kovács, A., Lugasi, A., Hagymási, K., Bíró, L. \& Fehér, J. (1999): Antioxidant defense in erythrocytes and plasma of patients with active and quiescent Crohn disease and ulcerative colitis: a chemiluminescent study. Clin. Chem., 45, 895-896.

Deiana, M., Loru, D., Incani, A., Rosa, A., Atzeri, A., Melis, M.P., Cabboi, B., Hollecker, L., Pinna, M.B., Argiolas, F., Murru, M. \& Dessì, M.A. (2012): Wine extracts from Sardinian grape varieties attenuate membrane oxidative damage in Caco-2 cell monolayers. Food Chem., 134, 2105-2113. 
Ferretti, G., Bacchetti, T., Masciangelo, S. \& Saturni, L. (2012): Celiac disease, inflammation and oxidative damage: a nutrigenetic approach. Nutrients, 4, 243-257.

Gujral, N., Freeman, H.J. \& Thomson, A.B. (2012): Celiac disease: prevalence, diagnosis, pathogenesis and treatment. World J. Gastroentero., 18, 6036-6059.

Horváth, É.M., Blázovics, A., Kemény, T., Vásárhelyi, B., Weinbrenner, Zs. \& Fehér, J. (1993): E-vitamin antioxidáns hatásának tanulmányozása kísérletesen létrehozott hiperlipidémiában (Antioxidant effect of vitamin E in experimental hyperlipidemia). Orvosi Hetilap, 134, 1757-1760.

Ieri, F., Martini, S., Innocenti, M. \& Mulinacci, N. (2013): Phenolic distribution in liquid preparations of Vaccinium myrtillus L. and Vaccinium vitis idaea L. Phytochem. Analysis, 24, 467-475.

Jovančević, M., Balijagić, J., Menković, N., Šavikin, K., Zdunić, G., Janković, T. \& Dekić-Ivanković, M. (2011): Analysis of phenolic compounds in wild populations of bilberry (Vaccinium myrtillus L.) from Montenegro. J. Med. Plant. Res., 5. 910-914.

KIM, J.G., KIM, H.L., Kim, S.J. \& PARK, K.S. (2013): Fruit quality, anthocyanin and total phenolic contents, and antioxidant activities of 45 blueberry cultivars grown in Suwon, Korea. J. Zhejiang Univ. Sci. B., 14, 793-799.

LeE, J. \& FinN, C. (2012): Lingonberry (Vaccinium vitis-idaea L.) grown in the Pacific Northwest of North America: Anthocyanin and free amino acid composition. J. Funct. Foods, 4, 213-218.

Lowry, A.H., Rosenbrough, N.J., Farr, A.L. \& Randall, R.J. (1951): Protein measurement with the Folin-phenol reagents. J. Biol. Chem., 193, 265-275.

Mikulic-Petkovsek, M., Slatnar, A., Stampar, F. \& Veberic, R. (2012): HPlC-MSn identification and quantification of flavonol glycosides in 28 wild and cultivated berry species. Food Chem., 135, 2138-2146.

National Institute of Pharmacy (2003): Pharmacopoea Hungarica. Editio VIII. Tomus I. Medicina Könyvkiadó Rt., Budapest, p. 232.

National Institute of Pharmacy (1986): Pharmacopoea Hungarica. Editio VII. Tomus III. Medicina Könyvkiadó, Budapest, pp. 1603-1604.

NiLE, S.H. \& PARK, S.W. (2014): Edible berries: Bioactive components and their effect on human health. Nutrition, 30, 134-144.

Oyaizu, M. (1986): Studies on products of browning reaction prepared from glucosamine. Jpn. J. Nutr., 44, 307-315.

Rutkowski, M. \& GrzegorczyK, K. (2012): Adverse effects of antioxidative vitamins. Int. J. Occup. Med. Env., 25, $105-121$.

Samoilova, Z., Smirnova, G., Muzyka, N. \& Oktyabrsky, O. (2014): Medicinal plant extracts variously modulate susceptibility of Escherichia coli to different antibiotics. Microbiol. Res., 169, 307-313.

Skesters, A., Kleiner, D., Blázovics, A., May, Z., Kurucz, D., Silova, A. \& Szentmihályi, K. (2014): Mineral element content and antioxidant capacity of some Latvian berries. Eur. Chem. Bull., 3, 98-101.

Souci-Fachmann-Kraut Food COMPosition AND NUtRition tables, MEDPHARM ONLINE DATABASE. (2014): medpharm GmbH Scientific Publishers. Stuttgart. Available at: http://www.sfk-online.net

Thilakarathna, S.H. \& Rupasinghe, H.P. (2013): Flavonoid bioavailability and attempts for bioavailability enhancement. Nutrients, 5, 3367-3387.

Timm, S., Svanes, C., Janson, C., Sigsgaard, T., Johannessen, A., Gislason, T., Jogi, R., Omenaas, E., Forsberg, B., Torén, K., Holm, M., BRÅвÄCK, L. \& Schlünssen, V. (2014): Place of upbringing in early childhood as related to inflammatory bowel diseases in adulthood: a population-based cohort study in Northern Europe. Eur. J. Epidemiol., 29, 429-437.

YANG, H. \& JIANG, Y. (2010): (Research progress of bioactive constituents. absorption. metabolism. and neuroprotective effects from blueberry.) (In Chinese). Wei Sheng Yan Jiu, 39, 525-528.

Yordi, E.G., Pérez, E.M., Matos, M.J. \& Villares, E.U. (2012): Antioxidant and pro-oxidant effects of polyphenolic compounds and structure-activity relationship evidence. -in: BOUAYED, J. (Ed.): Nutrition, well-being and health. InTech, Rijeka, Available at: http:/www.intechopen.com/books/nutrition-well-being-and-health/ 